\title{
A case of early onset renal sarcoidosis complecated with multiple enchondromatosis
}

\author{
U Kaneko*, S Toyabe, M Uchiyama \\ From 18th Pediatric Rheumatology European Society (PReS) Congress \\ Bruges, Belgium. 14-18 September 2011
}

\section{Background}

Early onset sarcoidosis (EOS) is a multisystem granulomatous disorder characterized by uveitis, arthritis, and skin rash with infiltration of noncaseating granuloma. Osseous and renal involvements are rare in EOS. Cystlike radiolucencies are predominant radiographic pattern of osseous sarcoisosis, which mimic enchondroma.

\section{Aim}

We present an unusual case of EOS with renal and osseous involvement. Histological findings of the kidney showed granulomatous interstitial nephritis, but bone biopsy indicated complication of enchondromatosis.

\section{Methods}

A five month old boy suffered from skin rash on his whole body after vaccination of BCG. At three years old, he developed fever and painless soft mass on his right ankle. Enhanced abdominal CT scan showed multiple low density lesions in both kidneys. He was initially diagnosed as having acute focal bacterial nephritis. However, antibiotics were not effective and he was referred to our hospital.

\section{Results}

Radiological findings of bone showed cyst-like radiolucencies in multiple regions such as phalanges of hand and feet, long bones, and pelvis. MRI showed tenosynovitis of ankle joint. Histological findings of skin, kidney, synovium and tendon sheath of ankle joint demonstrated the presence of non-caseating epithelioid granuloma. However, bone biopsy specimen revealed cartilage. He was diagnosed as having EOS complicated with multiple enchondromatosis. He was treated with

* Correspondence: utako-k@jc5.so-net.ne.jp

Department of Pediatrics, Niigata University Niigata, Japan oral corticosteroid at the dose of $1 \mathrm{mg} / \mathrm{kg}$, resulting in improvement of clinical symptoms.

\section{Conclusion}

There are no signs and symptoms at the onset of renal and osseous sarcoidosis. We may have to carefully exam these involvements even in EOS. The complication of enchondromatosis needs further investigation.

Published: 14 September 2011

doi:10.1186/1546-0096-9-S1-P8

Cite this article as: Kaneko et al:: A case of early onset renal sarcoidosis complecated with multiple enchondromatosis. Pediatric Rheumatology 2011 9(Suppl 1):P8.
Submit your next manuscript to BioMed Central and take full advantage of:

- Convenient online submission

- Thorough peer review

- No space constraints or color figure charges

- Immediate publication on acceptance

- Inclusion in PubMed, CAS, Scopus and Google Scholar

- Research which is freely available for redistribution
() Bïomed Central
C Biomed Central 